AMERICAN IMPERIALISM 


\section{BAAS Paperbacks}

\section{Published titles}

African American Visual Arts

Celeste-Marie Bernier

The American Short Story since I950

Kasia Boddy

American Imperialism: The Territorial

Expansion of the United States,

I783-20I3

Adam Burns

The Cultures of the American

New West

Neil Campbell

The Open Door Era: United States

Foreign Policy in the Twentieth

Century

Michael Patrick Cullinane and Alex

Goodall

Gender, Ethnicity and Sexuality in

Contemporary American Film

Jude Davies and Carol R. Smith

The United States and World War II:

The Awakening Giant

Martin Folly

The Sixties in America: History, Politics and Protest

M. J. Heale

Religion, Culture and Politics in the

Twentieth-Century United States

Mark Hulsether

The Civil War in American Culture

Will Kaufman

The United States and European

Reconstruction, I945-1960

John Killick

American Exceptionalism

Deborah L. Madsen

American Autobiography

Rachael McLennan

The American Landscape

Stephen F. Mills

Slavery and Servitude in North

America, I607-I 800

Kenneth Morgan
The Civil Rights Movement

Mark Newman

The Twenties in America: Politics and

History

Niall Palmer

American Theatre

Theresa Saxon

The Vietnam War in History, Literature

and Film

Mark Taylor

Contemporary Native American

Literature

Rebecca Tillett

Jazz in American Culture

Peter Townsend

The New Deal

Fiona Venn

Animation and America

Paul Wells

Political Scandals in the USA

Robert Williams

\section{Forthcoming titles}

The American Photo-Text, I930-1960

Caroline Blinder

The Beats: Authorship, Legacies

Robert A. Lee

American Detective Fiction

Ruth Hawthorn

Black Nationalism in American

History: From the Nineteenth Century

to the Million Man March

Mark Newman

Staging Transatlantic Relations,

I930-I960

Theresa Saxon

American Poetry since I900

Nick Selby

The US Graphic Novel

Paul Williams

edinburghuniversitypress.com/series/baas 


\title{
American Imperialism
}

\section{The Territorial Expansion of the United States, I783-20I3}

\author{
ADAM BURNS
}

\author{
EDINBURGH \\ University Press
}


Edinburgh University Press is one of the leading university presses in the UK. We publish academic books and journals in our selected subject areas across the humanities and social sciences, combining cutting-edge scholarship with high editorial and production values to produce academic works of lasting importance. For more information visit our website: edinburghuniversitypress.com

\section{(C) Adam Burns, 20I7}

Edinburgh University Press Ltd

The Tun - Holyrood Road, I2(2f) Jackson's Entry, Edinburgh EH8 8PJ

Typeset in Io/I2 Adobe Sabon by

IDSUK (DataConnection) Ltd, and

printed and bound in Great Britain by

CPI Group (UK) Ltd, Croydon CRo 4 YY

A CIP record for this book is available from the British Library

ISBN 978 I 4744 O2I 32 (hardback)

ISBN 978 I 4744 O2I 56 (webready PDF)

ISBN 978 I 4744 O2I 49 (paperback)

ISBN 978 I 4744 O2I 63 (epub)

The right of Adam Burns to be identified as the author of this work has been asserted in accordance with the Copyright, Designs and Patents Act I988, and the Copyright and Related Rights Regulations 2003 (SI No. 2498). 